\title{
THE POTENTIAL EFFICACY OF ALOE VERA GEL AND YUCCA SCHIDIGERA EXTRACT ON GROWTH PERFORMANCE, INTESTINAL LESIONS AND INFLAMMATORY RESPONSE IN BROILER CHICKENS CHALLENGED WITH COCCIDIA
}

\author{
GHADA ALLAM ABD EL -DAYEM ${ }^{1}$; REHAB R. ABD ELMAGED ${ }^{2}$ AND \\ NESMA RASHEED ${ }^{3}$ \\ ${ }^{1}$ Poultry Diseases Department, Animal Health Research Institute (AHRI) (Mansoura Branch), Agriculture \\ Research Center (ARC), Dokki, Giza, Egypt. \\ ${ }^{2}$ Parasitology Department, Animal Health Research Institute (AHRI) (Mansoura Branch), \\ Agriculture Research Center (ARC), Dokki, Giza, Egypt. \\ ${ }^{3}$ Pathology Department, Animal Health Research Institute (AHRI) (Mansoura Branch), \\ Agriculture Research Center (ARC), Dokki, Giza, Egypt.
}

Received: 28 March 2021; Accepted: 26 April 2021

\begin{abstract}
This study was conducted to investigate the effect of Aloe vera gel and Yucca schidigera extract supplementation on growth performance, oocyst shedding, intestinal lesions and inflammatory response in broilers challenged with coccidia. Two hundred and ten, one-day old Cobb chicks were randomly allocated to seven equal groups (30 birds/group). (G1): noninfected non-treated group, $(\mathrm{G} 2)$ : infected non-treated group, $(\mathrm{G} 3) \&(\mathrm{G} 4)$ : infected and treated with Aloe vera gel $5 \mathrm{gm} / \mathrm{L}$ and Yucca schidigera extract $200 \mathrm{mg} / \mathrm{L}$ respectively from $7^{\text {th }}$ day of age till the end of the experiment, (G5)\&(G6): infected and treated with Aloe vera gel $5 \mathrm{gm} / \mathrm{L}$ and Yucca schidigera extract $200 \mathrm{mg} / \mathrm{L}$ respectively from $15^{\text {th }}$ day of age till the end of the experiment and (G7): infected and treated with Amprolium 1g/ 2 L from $15^{\text {th }}$ day for five successive days. Chickens in infected groups were challenged with 50,000 sporulated oocysts of field strain of Eimeria spp. on the $14^{\text {th }}$ days of age. The average body weight gains, feed intake and feed conversion ratio were recorded all over the experimental period. The anticoccidial evaluation post infection depended on severity of bloody diarrhea, lesion scores as well as the oocyst shedding. In addition, histopathological changes in intestine and serum level of inflammatory cytokines were evaluated. Aloe vera gel and Yucca schidigera extract supplementation were able to mitigate the devastating effects of coccidia challenge in broilers. Growth performances represented by bodyweight gain, and feed conversion ratio were significantly improved. The Lesion score and oocysts shedding were significantly reduced as well as the serum level of pro-inflammatory (IL-6 and $I L-1 \beta$ ) were significantly down regulated in challenged treated groups. The histopathological changes of intestine were ameliorated in treated supplemented groups. In conclusion, Aloe vera gel and Yucca schidigera extract can be a promising candidate to be used as a natural, low cost alternative to control coccidiosis in chickens.
\end{abstract}

Keyword: broilers- Aloe vera- Yucca schidigera-performance-cytokines.

Corresponding author: Ghada Allam Abd El -Dayem

E-mail address: anasesra@gmail.com

Present address: Poultry Diseases Department, Animal Health Research Institute (AHRI) (Mansoura Branch), Agriculture Research Center (ARC), Dokki, Giza, Egypt. 


\section{INTRODUCTION}

Avian coccidiosis is one of the most economically important protozoan diseases in the broiler, caused by genus Eimeria. (Noack et al., 2019). E.acervulina, E.maxima and E.tenella are most frequently found in intensively poultry system and the latter is highly pathogenic (Thenmozhi et al., 2014; Clark et al., 2016). Coccidial infection damage the epithelial cells of the intestinal mucosal leading to nutrient malabsorption, inefficient feed utilization, poor growth rate, high mortality and secondary bacterial infections (Lee et al., 2012; Huang et al., 2018). Also, it cause economic losses due to increase costs of treatment and prophylaxis. Indeed in a subclinical form, it may cause immunosuppression that makes the bird more vulnerable to secondary disease conditions (Akhtar et al., 2012).

Chemoprophylaxis and anticoccidial feed additives have long been used as the main strategy to control avian coccidiosis .Unfortunately, the development of Eimeria strains resistance to multiple drugs and residues in poultry products may be potentially hazardous to consumers have made increasing interest for alternative products to control coccidiosis (Cervantes 2015). One of the ways, using botanicals in the control of avian coccidiosis, as they are novel natural products contains new therapeutic molecules to which immunity has not yet developed.

Aloe vera $(A V)$ (Aloe barbadensis Miller) is one of plants, having a great many medicinal and antibiotic properties (Christaki and FlorouPaneri 2010; Kar and Bera 2018). Aloe vera $(A V)$ contains over 75 bio-logically active compounds include anthraquinones, polysaccharides, vitamins, enzymes and low molecular weight compounds (Choi and Chung 2003) which gives Aloe vera antibacterial, antifungal, antiviral, anti-inflammatory, antioxidant and immunomodulatory properties (Ahlawat and Khatkar 2011; Radha and Laxmipriya 2015; Akram et al., 2019). Aloe vera gel contains polysaccharides, including acemannan which can improve the humoral immune response and cellular immunity (Du et al., 2011). Previous studies explained that Aloe vera has positive influence of on growth performance, gut microflora, and immune response (Kar and Bera 2018). Also, Aloe vera improved growth performance, reduced fecal oocyst shedding and lesion score in broilers challenged with coccidia (Yim et al., 2011; Akram et al., 2019; Ahmad et al., 2020).

Yucca schidigera (YS) is a natural, nontoxic product used commercially as a source of steroidal saponins. Moreover, it is a source of many polyphenolic compounds, such as resveratrol and a number of other phytochemicals like yuccaols (Alagawany et al., 2015). These chemical constituents have an antibacterial, anti-inflammatory, antioxidant and immunomodulatory effect (Cheeke et al., 2006). Dietary supplementation of Yucca schidigera extract improve nutrient digestibility, growth performance in broilers (Sahoo et al., 2015; Sun et al., 2017). Saponins improve the absorption of nutrients by the intestinal mucosal surface (Barnes et al., 2003). Several studies have shown Anticoccidial effect of Yucca schidigera extract in broilers (Djezzar et al., 2014; Bafundo et al., 2020).

Keeping in view of the facts stated above, the present study was planned to investigate the beneficial effects of Aloe vera gel and Yucca schidigera extract on growth performance, lesion score, oocyst shedding, histopathological changes and inflammatory response in broilers experimentally infected with coccidia.

\section{MATERIALS AND METHODS}

\section{Herb extracts and anticoccidial drug:}

Aloe vera gel: The plant part (leaves) was identified by a taxonomist in Faculty of Agriculture Mansoura University. The mucilaginous leaf gel was separated from $A$. vera leaves within 3-4 $\mathrm{h}$ post collection to avoid aero deterioration of gel contents according to the method described by Lin et al. (2005) and Isah et al. (2019). Gently, the prewashed $A$. vera leaves were incised longitudinally with the 
help of a sharp sterilized knife followed by gentle scraping of gel using a spatula. The gel was homogenized, filtered through cheesecloth and stored in screw-capped jars at $4{ }^{\circ} \mathrm{C}$ till further use.

Yucca schidigera extract: Yucca extract as a commercial product (Santufo Logestics Corporation, Canda). Each liter contain $\mathrm{Yucca}$ schidigera extract 200gm (saponin 10gm), Mann oligosaccharides $10 \mathrm{gm}$, citric acid (98\%) $10 \mathrm{gm}$, sodium benzoate $5 \mathrm{gm}$ and purified water up to 1 liter.

\section{Eimeria Challenge:}

Field intestinal strains of Eimeria spp were subjected to isolation, propagation, purification and sporulation as described by (Tanweer et al., 2014). Briefly, the intestine of the infected birds were collected. The contents of the gut were collected and soaked overnight in $2.5 \%$ potassium dichromate solution. The suspension was filtered and centrifuged at $1500 \mathrm{rpm}$ for 3 min. The supernatant was discarded, and the sediment was resuspended in a saturated solution of sodium chloride and centrifuged at1500 rpm for $3 \mathrm{~min}$. The sediment containing oocysts was separated and kept in incubator at $30{ }^{\circ} \mathrm{C}$ for $24-72 \mathrm{~h}$. The sporulated oocysts were stored at $4{ }^{\circ} \mathrm{C}$ in potassium dichromate solution, McMaster technique was used for counting of oocyst (Gibbons et al., 2016). Then were inoculated intra crop in broiler chickens in a dose of o 50,000 sporulated oocysts at $14^{\text {th }}$ day of age (Munir et al., 2018) except negative control.

Experimental Animals and study groups: A total of 210 one-day old Cobb chicks were divided into equal seven groups, each of 30 birds (3 replicates / group). The birds were fed with coccidiostat free experimental feed. The birds were vaccinated with New Castle Disease (ND) and Infectious Bronchitis (IB) at day 1, Infectious Bursal Disease (IBD) at day 8 and then ND at 14 day.

Group1(G1): non challenged and nontreated.

Group 2(G2): challenged and non treated.
Group 3(G3): challenged and treated with Aloe vera gel $5 \mathrm{gm} / \mathrm{L}$ from $7^{\text {th }}$ day of age till the end of the experiment.

Group 4(G4): challenged and treated with Yucca schidigera extract $200 \mathrm{mg} / \mathrm{L}$ from $7^{\text {th }}$ day of age till the end of the experiment.

Group 5(G5): challenged and treated Aloe vera gel $5 \mathrm{gm} / \mathrm{L}$ from $15^{\text {th }}$ day of age till the end of the experiment.

Group (G6): challenged and treated with Yucca schidigera extract $200 \mathrm{mg} / \mathrm{L}$ from $15^{\text {th }}$ day of age till the end of the experiment.

Group7 (G7): challenged and treated with Amprolium1g/ $2 \mathrm{~L}$ of water from $15^{\text {th }}$ day of age for five successive days.

The broiler chickens were fed ad libitum and they received a lighting regimen of $23 \mathrm{~h}$ light: 1 $\mathrm{h}$ darkness. The initial temperature was $32{ }^{\circ} \mathrm{C}$ which gradually reduced according to breeding standards. Control parameters, such as temperature, humidity, light and ventilation, were the same for all treatments.

\section{Evaluation of supplementation effectiveness: Performance parameters:}

Feed intake and body weight gain were weekly recorded throughout the study. Feed Conversion ratio were calculated (total feed intake / body weight gain) (Sainsbury 1984).

\section{Anticoccidial evaluation:}

At days 7 and 14 post infection, three chickens from each group were selected randomly and killed. Intestines along with caeca were removed from the infected birds for the lesion scores $(0$ to +4 counting system $)$ as described by (Tanweer et al., 2014). The lesions were comprised of petechial hemorrhages, thickening of wall, bloody fecal contents, and mucoid discharge. Based upon the severity of the lesions, a score of 0 (no lesions), 1 (mild lesions), 2 (moderate lesions), 3 (severe lesions), or 4 (extremely severe lesions). The bloody diarrhea score for fecal materials as excreted droppings from each group was 
determined on a scale from 0 to 4 using previously described methods (Youn and Noh 2001) as well as the number of oocyst per gram feces excreted ( OPG) on $3^{\text {rd }}, 5^{\text {th }}, 7^{\text {th }}, 9^{\text {th }}$ and $11^{\text {th }}$ days post infection (dpi) by the modified McMaster technique as described by (Alnassan et al., 2013). The reduction in oocyst production (ROP) was calculated with the formula $\mathrm{ROP}=$ (oocyst output of positive control group - oocyst output of negative control or medicated groups) $\times 100 /$ oocyst output of the positive control group.

Inflammatory responses in serum: At 5 and 10 day post challenge three blood samples were collected from each group. Serum sample were centrifuged at $3000 \mathrm{rpm}$ for $5 \mathrm{~min}$. The collected sera were subjected to determination of interleukinIL-1 $\beta$ and IL6 concentrations by using ELISA kits (Becton, Dickinson and Company, Franklin Lakes, NJ) following the manufacturer's instructions.

Pathological assay: At first week post infection (two weeks post treatment for G3\&G4 and one week post treatment for G5, G6 \&G7) and after 2 weeks post infection (three weeks post treatment for G3\&G4 and two weeks post treatment for G5, G6\&G7), three bird /group were euthanized by neck severing and necropsied. Samples of about two centimeters from the intestine (duodenum, jejunum and ileum) and cecum were cut, pinned and stowed in $10 \%$ buffered formalin solution. The samples were processed by routine histology methods, embedded longitudinally in paraffin, sectioned $5 \mu \mathrm{m}$ thick parallel to the cut edge and stained with hematoxylin and eosin (H\&E) (Suvarna et al., 2018).

\section{Statistical analysis:}

Differences between groups were analyzed by using One-Way ANOVA and Duncan's multiple comparison Post Hoc tests

\section{RESULTS}

\section{Growth performance parameters:}

Our results showed that there was significant increase $(\mathrm{p}<0.05)$ in body weight gain and significant decrease $(\mathrm{p}<0.05)$ in feed conversion ratio in all challenged treated groups as compared with control positive group (G2). Chickens in groups (G3\&G4) administered with Aloe vera gel and Yucca schidigera extract before infection showed significantly higher ( $p$ $<0.05$ ) body weight gains as compared with (G7) treated with amprolium and (G5\&G6) administered with Aloe vera gel and Yucca schidigera extract after infection. In addition, there was significant difference $(p<0.05)$ in body weight and body weight gain between G3\&G4. while, there was no significant difference $(p>0.05)$ in body weight and body weight gain between G5\&G6. Birds from the positive control treatment showed highest FCR $(P<0.05)$ compared to all other challenged treatments. There was no significant difference ( $p>0.05)$ in FCR between all challenged treated groups (Table 1).

\section{Clinical signs:}

In this study, no clinical abnormalities were observed in chickens of the control group (G1), while, chickens in positive control group (G2) exhibited the typical symptoms of coccidiosis including depression, dullness, ruffled feathers, reduction of feed intake, and blood stained whitish to brownish diarrhea, accompanied with progressive weakness leading to death within 3-5 days after infection. The severity of clinical signs in G7, G3and G4 was less sever than G5\&G6.

\section{Bloody diarrhea:}

After infection, bloody diarrhea was observed in control positive groups (G2) from 3 DPI. and in infected treated groups, started one day later. The severity of bloody diarrhea in all infected treated groups was milder compared with the infected non treated groups. The severity of bloody diarrhea was milder in (G7, G3 \&G4) than (G5\&G6). Only one chick died from G3,G4\&G6, 2 out of G5, while 4 from G2, whereas no deaths were recorded in both $\mathrm{G} 1$ and G7as shown in Table(2).

\section{Lesion score:}

Regarding to the effect of different treatments on lesion score, our results showed that there 
was a significant decrease $(\mathrm{p}<0.05)$ in intestinal lesion score in all infected treated groups as compared with control positive group (G2). The most significant decrease was observed in G7 and G4 as compared with G3, G5 and G6 $(\mathrm{P}<0.05)$ (table3).

\section{Oocysts output:}

The effect of the dietary treatments on fecal oocyst excretion in broiler chickens post infection is presented in table 4. Fecal oocyst excretion peaked at 5,6 and $7 \mathrm{dpi}$ and then declined again gradually. The faecal oocyst counts in G3, G4 G5, G6\&G7 were significantly $(\mathrm{P}<0.05)$ lower as compared with positive control group (G2). The G7, G4\&G3had the lowest number of oocyst count with an ROP value of $76.52 \%, 45.31 \%$ \&39.89\% respectively.

\section{Pro inflammatory cytokine serum level:}

Our results showed that coccidia infection significantly $(\mathrm{p}<0.05)$ up regulate pro inflammatory cytokine IL- $1 \beta$ and IL- 6 in all challenged groups as compared to control negative group (G2). Aloe vera gel and Yucca schidigera extract significantly down regulate $(\mathrm{P}<0.05)$ expression of pro inflammatory cytokines as compared to control positive group (G2). There was significant decrease $(\mathrm{P}<0.05)$ in pro inflammatory cytokines levels in G3, G4 \&G7 as compared to G5\&G6. (fig1 A\&B).

\section{Histopathological finding:}

At first week post infection(two weeks post treatment for $\mathrm{G} 3 \& \mathrm{G} 4$ and one week post treatment for G5,G6\&G7), intestine in infected untreated group (G2) showed involvement of the intestinal crypts and glands by the different developmental stages of coccidia, desquamated mucosal epithelia, inflammatory cells (eosinophils \& plasma cell) and extravasated erythrocytes in the intestinal lumina (Fig 2A). Epithelial cells were markedly degenerated and necrotic. Ball-Like collections of coccidial developmental stages were seen replacing most of the intestinal glands. Superficial mucosal necrosis and desquamation could be detected (Fig 2B). Large intestine in (G3) showed different developmental stages of coccidia including gametes and oocytes and moderate round cells infiltration, mainly lymphocytes and plasma cells in submucosa (Fig3). The superficial cecal mucosa revealed surface epithelial atrophy and degeneration. While, in G5 large intestine represented severe submucosal vascular hyperemia, hemorrhages, large number of coccidial developmental stages with partial or complete replacement and destruction of the glandular epithelium (fig4). Cecum in (G4) showed moderate involvement of intestinal crypts by degenerated developmental stages of coccidian with moderate round cells infiltration ( plasma cells) in submucosa (Fig5). while, in (G6) large intestine showed developmental stages of coccidia in the intestinal crypts and glands with complete or partial replacements of their epithelial lining (Fig6) and moderate submucosal infiltration by round cells. Large intestine in G7 demarcated failure of the traditional anticoccidial drug from complete relief and healing of the pre-existing coccidial lesions at this time schedule of the experiment with still presence developmental stages, although some were degenerated particularly in the intestinal glands (Fig7).

After 2 weeks post infection(three weeks post treatment for G3\&G4 and two weeks post treatment for G5, G6 \&G7) large intestine of (G3) revealed characteristic therapy effect of the used supplemention, where large number of the still existing coccidial developmental stages were deformed (Fig8). The submucosa showed mild to moderate infiltration of round cells. The mucosal and submucosal epithelial cells were regenerated and appeared healthy with presence of variable number of goblet cells. While, (G5) showed large number of coccidial oocytes in cecal lumen, some of them appeared deformed or degenerated with absence of inflammatory or blood exudates. The intestinal crypts and glands showed moderate involvement of their epithelia by developmental stages of coccidia, many of them were degenerated (Fig 9). Examined sections from intestines of ( $\mathrm{G} 4$ ) pointed out the most promising and innovated plant extract compounds as nearly most of the intestinal crypts and glands were free from any of the coccidial developmental stages, 
with marked regenerative changes in the epithelial cells (Fig10). While in (G6) large intestine showed a previously existing remnants from coccidial developmental stages, most of them were degenerated. The mucosal and glandular epithelium appeared regenerated with large hyperchromatic nuclei (Fig 11). Large intestine of G7, most of the intestinal crypts and glands were free from any of the parasitic developmental stages and the previously infested cells exhibited regenerative changes. Mild submucosal infiltration of round cells. (Fig 12).

Table 1: Effect of Aloe vera gel and Yucca schidigera extract on growth performance parameters in broilers chickens experimentally challenged with coccidia.

\begin{tabular}{|c|c|c|c|c|c|c|c|c|}
\hline & & G1 & $\mathrm{G} 2$ & G3 & G4 & G5 & G6 & G7 \\
\hline 7day & B W & $\begin{array}{c}164.3 \pm \\
0.75^{\mathrm{a}}\end{array}$ & $\begin{array}{c}165.3 \pm \\
0.75^{\mathrm{a}}\end{array}$ & $\begin{array}{c}164.3 \\
\pm 0.48^{\mathrm{a}}\end{array}$ & $\begin{array}{c}166.3 \pm \\
1.2^{\mathrm{a}}\end{array}$ & $\begin{array}{c}164.3 \pm \\
0.47^{\mathrm{a}}\end{array}$ & $\begin{array}{l}165 \pm \\
0.82^{\mathrm{a}}\end{array}$ & $\begin{array}{c}163.3 \pm \\
1.2^{\mathrm{a}}\end{array}$ \\
\hline \multirow[t]{4}{*}{ 14day } & B W & $\begin{array}{c}25.25 \pm \\
0.85^{\mathrm{C}} \\
\end{array}$ & $\begin{array}{c}23.7 \pm \\
0.75^{\mathrm{C}} \\
\end{array}$ & $\begin{array}{c}335.75 \pm \\
0.47^{\mathrm{b}} \\
\end{array}$ & $\begin{array}{c}440.5 \pm \\
1.3^{\mathrm{a}} \\
\end{array}$ & $\begin{array}{c}424.7 \pm \\
0.47^{\mathrm{C}} \\
\end{array}$ & $\begin{array}{c}422 \\
\pm 0.4^{\mathrm{C}} \\
\end{array}$ & $\begin{array}{l}421 \pm \\
0.65^{\mathrm{C}} \\
\end{array}$ \\
\hline & BWG & $260.95^{\mathrm{b}}$ & $258.4^{\mathrm{b}}$ & $271.45 \mathrm{a}$ & $274.2^{\mathrm{a}}$ & $260.4^{\mathrm{b}}$ & $257^{\mathrm{b}}$ & $257.7^{\mathrm{b}}$ \\
\hline & FI & 335 & 335 & 347 & 354 & 334 & 330 & 330 \\
\hline & FCR & $1.27 \pm 0.02^{\mathrm{a}}$ & $\begin{array}{l}1.30 \pm \\
0.01^{\mathrm{a}} \\
\end{array}$ & $\begin{array}{l}1.28 \pm \\
0.01^{\mathrm{a}} \\
\end{array}$ & $\begin{array}{l}1.29 \pm \\
0.05^{\mathrm{a}} \\
\end{array}$ & $\begin{array}{l}1.28 \pm \\
0.01^{\mathrm{a}} \\
\end{array}$ & $\begin{array}{l}1.28 \pm \\
0.01^{\mathrm{a}} \\
\end{array}$ & $\begin{array}{l}1.28 \pm \\
0.09^{\mathrm{a}} \\
\end{array}$ \\
\hline \multirow[t]{4}{*}{ 21day } & $\mathrm{BW}$ & $\begin{array}{c}854.7 \pm \\
1.24^{\mathrm{a}} \\
\end{array}$ & $\begin{array}{c}797.25 \pm \\
1.11^{\mathrm{e}} \\
\end{array}$ & $\begin{array}{c}831.3 \pm \\
1.03^{\mathrm{c}} \\
\end{array}$ & $\begin{array}{c}838.75 \pm \\
1.2^{\mathrm{b}} \\
\end{array}$ & $\begin{array}{c}815.3 \pm \\
0.85^{\mathrm{e}} \\
\end{array}$ & $\begin{array}{c}817 \pm \\
0.58^{\text {de }} \\
\end{array}$ & $\begin{array}{l}821 \pm \\
0.71^{\mathrm{d}} \\
\end{array}$ \\
\hline & BWG & $\begin{array}{c}429.45 \pm \\
0.88^{\mathrm{a}} \\
\end{array}$ & $\begin{array}{c}373.25 \pm \\
1.5^{\mathrm{e}} \\
\end{array}$ & $\begin{array}{c}396.3 \pm \\
1.2^{\mathrm{bc}} \\
\end{array}$ & $\begin{array}{c}398.75 \pm \\
1^{\mathrm{b}} \\
\end{array}$ & $\begin{array}{c}390.6 \pm \\
0.88^{\mathrm{d}} \\
\end{array}$ & $\begin{array}{l}394 \pm \\
1.4^{\text {cd }} \\
\end{array}$ & $\begin{array}{l}400 \pm \\
1.7^{\mathrm{b}} \\
\end{array}$ \\
\hline & FI & 562 & 525 & 545 & 533 & 530 & 535 & 540 \\
\hline & FCR & $1.3 \pm 0.01^{\mathrm{c}}$ & $\begin{array}{l}1.41 \pm \\
0.03^{\mathrm{a}} \\
\end{array}$ & $\begin{array}{l}1.36 \pm \\
0.01^{\mathrm{b}} \\
\end{array}$ & $\begin{array}{l}1.35 \pm \\
0.02^{\mathrm{b}} \\
\end{array}$ & $\begin{array}{l}1.36 \pm \\
0.01^{\mathrm{b}} \\
\end{array}$ & $\begin{array}{l}1.36 \pm \\
0.02^{\mathrm{b}} \\
\end{array}$ & $\begin{array}{l}1.35 \pm \\
0.02^{\mathrm{b}} \\
\end{array}$ \\
\hline \multirow[t]{4}{*}{ 28day } & $\mathrm{BW}$ & $\begin{array}{c}1373.75 \pm \\
1.25^{\mathrm{a}} \\
\end{array}$ & $\begin{array}{c}1278.5 \pm \\
0.95^{\mathrm{f}} \\
\end{array}$ & $\begin{array}{c}1341 \pm \\
0.85^{\mathrm{c}} \\
\end{array}$ & $\begin{array}{c}1360.75 \pm \\
0.7^{\mathrm{b}} \\
\end{array}$ & $\begin{array}{c}1314 \pm \\
0.8^{\mathrm{e}}\end{array}$ & $\begin{array}{c}1318 \pm \\
0.71^{\mathrm{e}} \\
\end{array}$ & $\begin{array}{c}1331 \pm \\
0.85^{\mathrm{d}} \\
\end{array}$ \\
\hline & BWG & $519 \pm 0.7^{a}$ & $\begin{array}{c}481.25 \pm \\
0.9^{\mathrm{d}} \\
\end{array}$ & $\begin{array}{c}510.7 \pm \\
0.4^{\mathrm{b}} \\
\end{array}$ & $\begin{array}{c}522 \pm \\
0.82^{\mathrm{a}} \\
\end{array}$ & $\begin{array}{c}498.7 \pm \\
1.1^{\mathrm{c}} \\
\end{array}$ & $\begin{array}{c}499 \pm \\
1.2^{\mathrm{c}} \\
\end{array}$ & $\begin{array}{c}510 \pm \\
0.9^{\mathrm{b}} \\
\end{array}$ \\
\hline & FI & 843 & 830 & 840 & 853 & 825 & 835 & 847 \\
\hline & FCR & $1.62 \pm 0.0^{b}$ & $\begin{array}{l}1.72 \pm \\
0.01^{\mathrm{a}} \\
\end{array}$ & $\begin{array}{l}1.64 \pm \\
0.02^{\mathrm{b}} \\
\end{array}$ & $\begin{array}{l}1.64 \pm \\
0.02^{\mathrm{b}} \\
\end{array}$ & $\begin{array}{l}1.65 \pm \\
0.00^{\mathrm{b}} \\
\end{array}$ & $\begin{array}{l}1.66 \pm \\
0.03^{\mathrm{b}} \\
\end{array}$ & $\begin{array}{l}1.66 \pm \\
0.01^{b} \\
\end{array}$ \\
\hline \multicolumn{9}{|l|}{ overall } \\
\hline & BWG & $\begin{array}{c}1209.45 \pm \\
0.41^{\mathrm{a}} \\
\end{array}$ & $\begin{array}{c}1113.2 \pm \\
0.48^{\mathrm{f}} \\
\end{array}$ & $\begin{array}{c}1176.7 \pm \\
0.65^{\mathrm{c}} \\
\end{array}$ & $\begin{array}{c}1194.45 \pm \\
0.7^{\mathrm{b}} \\
\end{array}$ & $\begin{array}{c}1149.7 \pm \\
0.29^{\mathrm{e}} \\
\end{array}$ & $\begin{array}{c}1153 \pm \\
0.91^{\mathrm{e}} \\
\end{array}$ & $\begin{array}{c}1167.7 \pm \\
0.47^{\mathrm{d}} \\
\end{array}$ \\
\hline & FI & 1740 & 1690 & 1732 & 1740 & 1689 & 1700 & 1717 \\
\hline & FCR & $1.43 \pm 0.00^{\mathrm{c}}$ & $\begin{array}{l}1.52 \pm \\
0.09^{\mathrm{a}} \\
\end{array}$ & $\begin{array}{l}1.46 \pm \\
0.01^{\mathrm{bc}} \\
\end{array}$ & $\begin{array}{l}1.46 \pm \\
0.01^{\mathrm{bc}} \\
\end{array}$ & $\begin{array}{l}1.47 \pm \\
0.00^{\mathrm{b}} \\
\end{array}$ & $\begin{array}{l}1.47 \pm \\
0.01^{\mathrm{b}} \\
\end{array}$ & $\begin{array}{l}1.47 \pm \\
0.02^{\mathrm{b}} \\
\end{array}$ \\
\hline
\end{tabular}

SEM=Standard Error of Mean. a-e Values followed by different superscript letters were significantly different at $(\mathrm{P}<0.05)$.

(G1): non challenged and non treated; (G2): challenged and non treated. (G3): challenged and treated with Aloe vera gel $5 \mathrm{gm} / \mathrm{L}$ from 7 th day of age till the end of the experiment; (G4): challenged and treated with Yucca schidigera extract $200 \mathrm{mg} / \mathrm{L}$ from $7^{\text {th }}$ day of age till the end of the experiment. (G5): challenged and treated Aloe vera gel $5 \mathrm{gm} / \mathrm{L} 15^{\text {th }}$ day of age till the end of the experiment. (G6): challenged and treated with Yucca schidigera extract $200 \mathrm{mg} / \mathrm{L}$ from $15^{\text {th }}$ day of age till the end of the experiment. (G7): challenged and treated with Amprolium1g/ $2 \mathrm{~L}$ of water from $15^{\text {th }}$ day of age for five successive days 
Table 2: Effect of Aloe vera gel and Yucca schidigera extract on severity of bloody diarrhea and number of deaths in broilers chickens experimentally challenged with coccidia

\begin{tabular}{|c|c|c|c|c|c|c|c|c|c|c|}
\hline \multirow[t]{2}{*}{ GROUP } & \multicolumn{9}{|c|}{$\begin{array}{c}\text { No. of birds with bloody diarrhea at different } \\
\text { days post infection }\end{array}$} & \multirow{2}{*}{ No .of deaths } \\
\hline & 2 & 3 & 4 & 5 & 6 & 7 & 8 & 9 & 10 & \\
\hline G1 & 0 & 0 & 0 & 0 & 0 & 0 & 0 & 0 & 0 & 0 \\
\hline G2 & 0 & 1 & 2 & 3 & 3 & 2 & 1 & 1 & 0 & 4 \\
\hline G3 & 0 & 0 & 2 & 2 & 1 & 1 & 0 & 0 & 0 & 1 \\
\hline G4 & 0 & 0 & 2 & 1 & 1 & 0 & 0 & 0 & 0 & 1 \\
\hline G5 & 0 & 0 & 2 & 2 & 1 & 1 & 1 & 0 & 0 & 2 \\
\hline G6 & 0 & 0 & 2 & 2 & 1 & 1 & 0 & 0 & 0 & 1 \\
\hline G7 & 0 & 0 & 1 & 1 & 1 & 0 & 0 & 0 & 0 & 0 \\
\hline
\end{tabular}

Table 3: effect of Aloe vera gel and Yucca schidigera extract on lesion scores in broilers chickens experimentally challenged with coccidia

\begin{tabular}{|c|c|c|}
\hline \multirow{2}{*}{ group } & \multicolumn{2}{|c|}{ Lesion scores } \\
\hline & 7dpi & 14dpi \\
\hline G1 & $0 \pm 0.0^{\mathrm{d}}$ & $0 \pm 0.0^{\mathrm{d}}$ \\
\hline $\mathrm{G} 2$ & $3.7 \pm 0.3^{\mathrm{a}}$ & $2.3 \pm 0.0^{\mathrm{a}}$ \\
\hline G3 & $2 \pm 0.3^{\mathrm{bc}}$ & $1.3 \pm 0.3^{\mathrm{ab}}$ \\
\hline G4 & $1.7 \pm 0.0^{\mathrm{bc}}$ & $1 \pm 0.0^{b}$ \\
\hline G5 & $2.7 \pm 0.3^{b}$ & $1.7 \pm 0.3^{\mathrm{ab}}$ \\
\hline G6 & $2.7 \pm 0.3^{b}$ & $1.7 \pm 0.0^{\mathrm{ab}}$ \\
\hline G7 & $1.3 \pm 0.3^{\mathrm{c}}$ & $0.7 \pm 0.0^{\mathrm{b}}$ \\
\hline
\end{tabular}

Table 4: effect of Aloe vera gel and Yucca schidigera extract on oocyst output in broilers chickens experimentally challenged with coccidia

\begin{tabular}{ccccccc}
\hline groups & \multicolumn{7}{c}{ Oocysts excretion $\left(10^{3} / \mathrm{g}\right.$ excreta) } \\
\hline G1 & $3 \mathrm{dpi}$ & $5 \mathrm{dpi}$ & $7 \mathrm{dpi}$ & $9 \mathrm{pdi}$ & $11 \mathrm{dpi}$ & $\mathrm{ROP}(\%)$ \\
\hline $\mathrm{G} 2$ & $28.276 \pm 463^{\mathrm{a}}$ & $62.166 \pm 811^{\mathrm{a}}$ & $182.9 \pm 1493^{\mathrm{a}}$ & $39.303 \pm 585^{\mathrm{a}}$ & $11.390 \pm 593^{\mathrm{a}}$ & - \\
\hline $\mathrm{G} 3$ & $12.700 \pm 564^{\mathrm{c}}$ & $20.933 \pm 548^{\mathrm{c}}$ & $35.345 \pm 642^{\mathrm{c}}$ & $12.500 \pm 472^{\mathrm{c}}$ & $4.450 \pm 444^{\mathrm{c}}$ & 39.89 \\
\hline $\mathrm{G} 4$ & $11.433 \pm 611^{\mathrm{c}}$ & $18.633 \pm 845 \mathrm{~d}$ & $33.66 \pm 683^{\mathrm{d}}$ & $10.300 \pm 472^{\mathrm{d}}$ & $4.450 \pm 444^{\mathrm{c}}$ & 45.31 \\
\hline $\mathrm{G} 5$ & $14.733 \pm 405^{\mathrm{b}}$ & $24.400 \pm 472^{\mathrm{b}}$ & $37.600 \pm 435^{\mathrm{b}}$ & $14.33 \pm 423^{\mathrm{b}}$ & $5.543 \pm 166^{\mathrm{b}}$ & 32.43 \\
\hline G6 & $14.433 \pm 448^{\mathrm{b}}$ & $23.200 \pm 838^{\mathrm{b}}$ & $37.400 \pm 682^{\mathrm{b}}$ & $13.233 \pm 491^{\mathrm{bc}}$ & $5.266 \pm 202^{\mathrm{b}}$ & 34.30 \\
\hline G7 & $8100 \pm 550^{\mathrm{e}}$ & $12.200 \pm 519^{\mathrm{e}}$ & $16.600 \pm 240^{\mathrm{e}}$ & $6750 \pm 240^{\mathrm{e}}$ & $2.100 \pm 57^{\mathrm{d}}$ & 76.52 \\
\hline
\end{tabular}



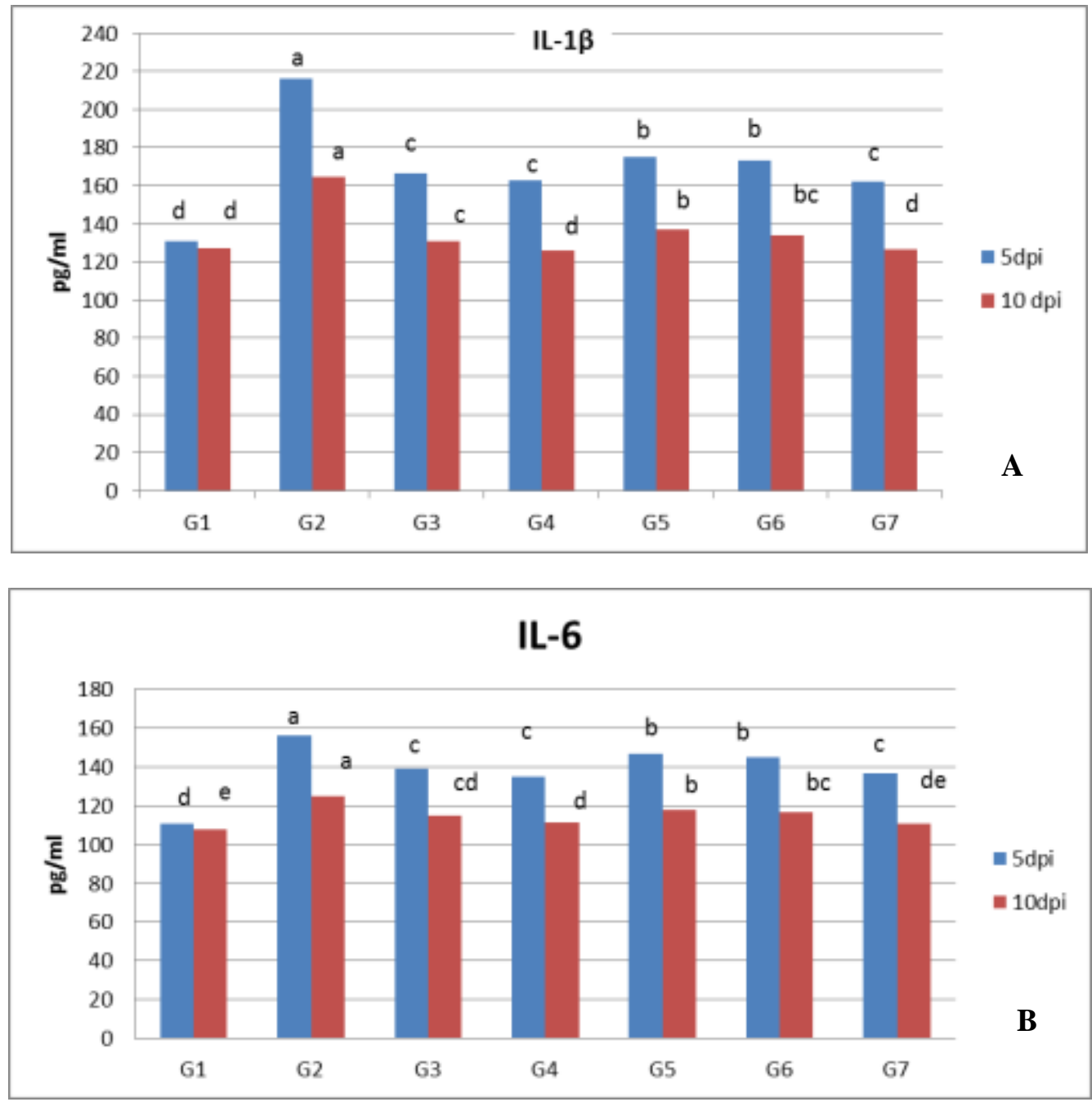

Fig. (1): Effect of Aloe vera gel and Yucca schidigera extract on serum level of proinflammatory cytokines in broilers chickens experimentally challenged with coccidia.

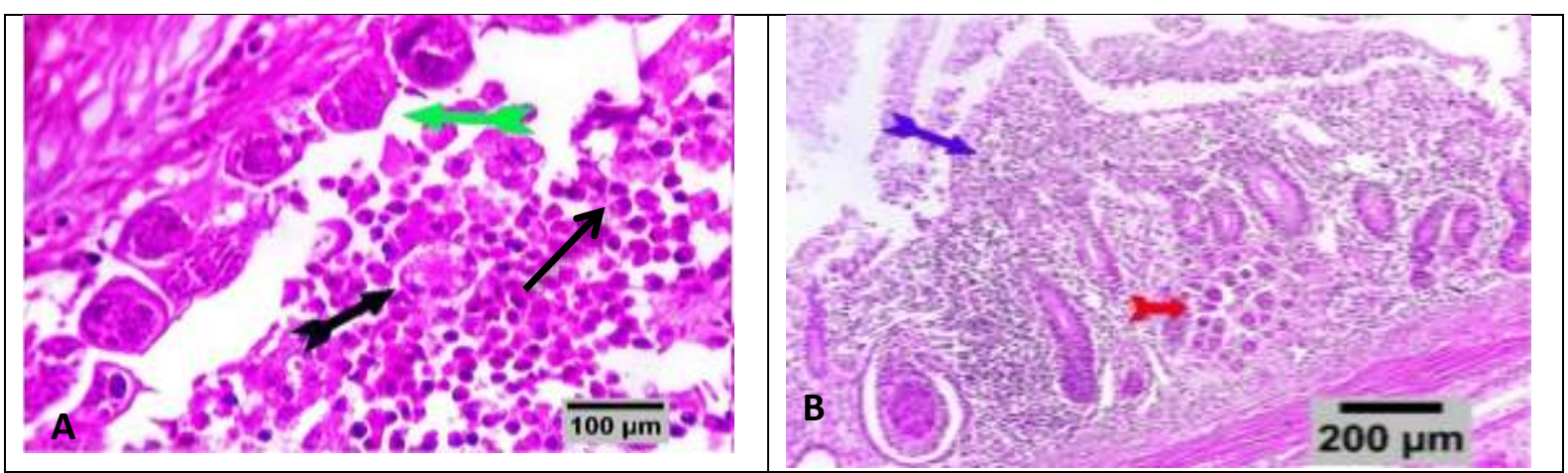

Fig. (2): large intestines from (G 2) showing developmental stages of coccidia (green arrows). Infiltration of submucosa by inflammatory cells, eosinophils, plasma cells and extravasated erythrocytes (black arrows) (A). Epithelial cells were degenerated and necrotic (blue arrow) coocidial developmental stages replacing the intestinal glands (red arrow) (B). Scale bars 100 um, 200 um. H\&E stain 


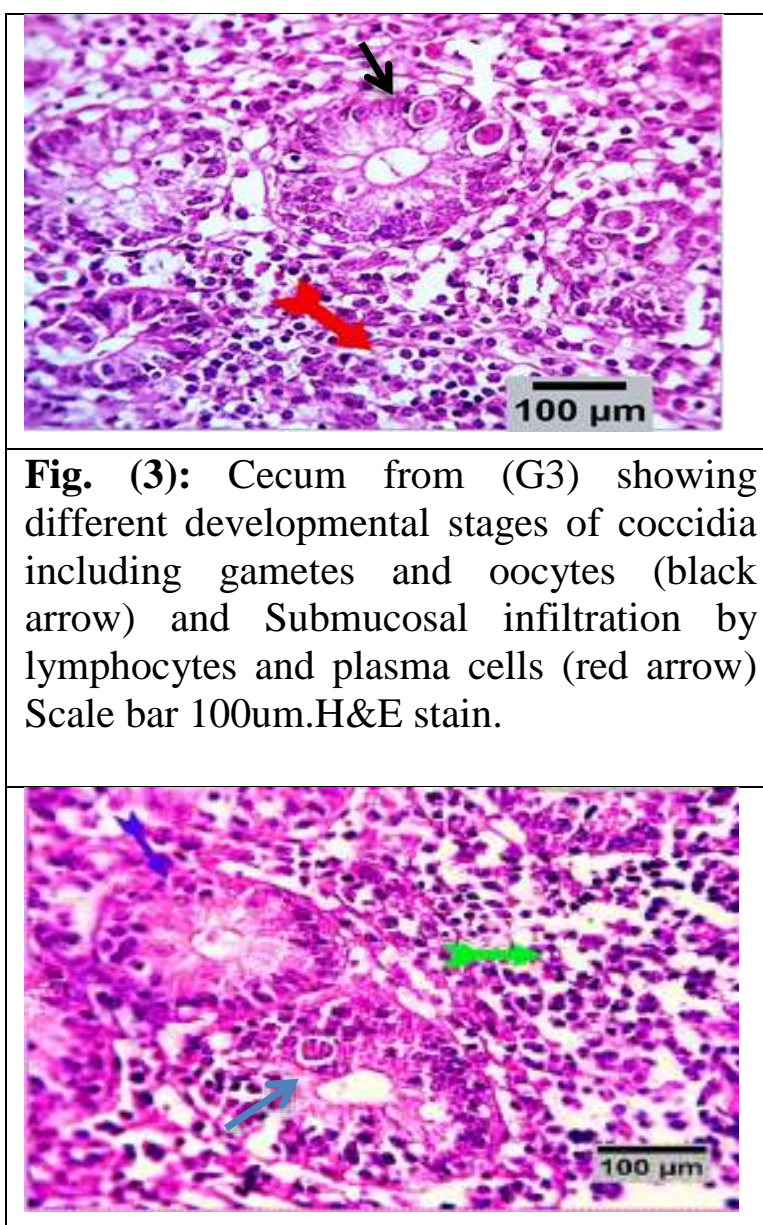

Fig. (5): Large intestine from (G4) showing degenerated coccidial stages (blue arrows) and infiltration of submucosa by round cells mainly plasma cells (green arrow). Scale bar 100 um H\&E stain.

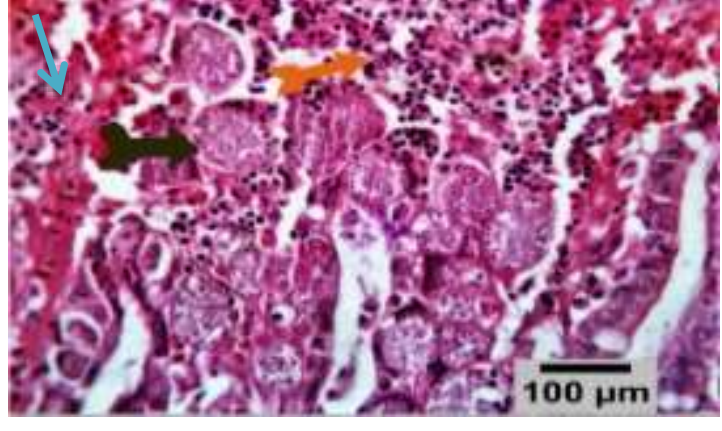

Fig. (4): Large intestine from (G5) showing submucosal vascular hyperemia, hemorrhages (blue arrow). Destruction of glandular epithelium (black arrow). Infiltration of the submucosa by round cells (orange arrow). Scale bars 100 um H\&E stain.

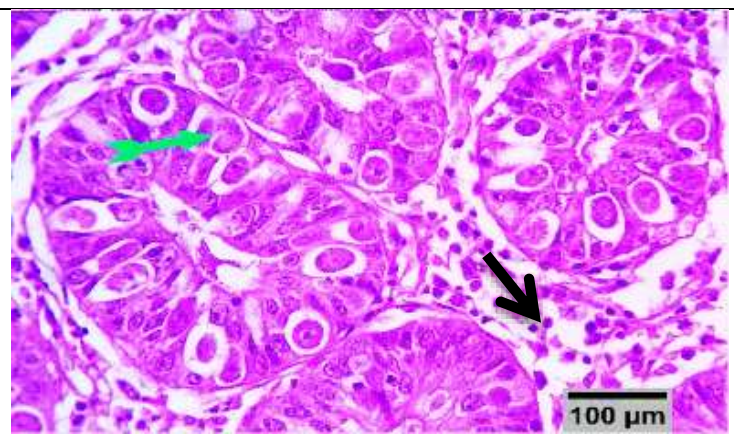

Fig. (6): Large intestine from (G6) showing different developmental stages of coccidia in the intestinal crypts and glands (green arrow) and Submucosal infiltration by round cells (black arrow). Scale bar 100 um H\&E stain.

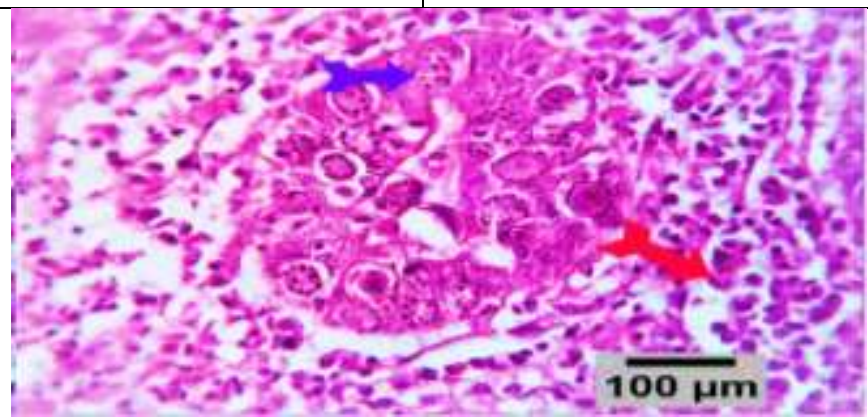

Fig. (7): large intestines from (G7), showing degenerated coccidial developmental stages in the intestinal glands (blue arrow). The submucosa is moderately infiltrated by round cells (red arrow). Scale bar100 um. H\&E stain. 


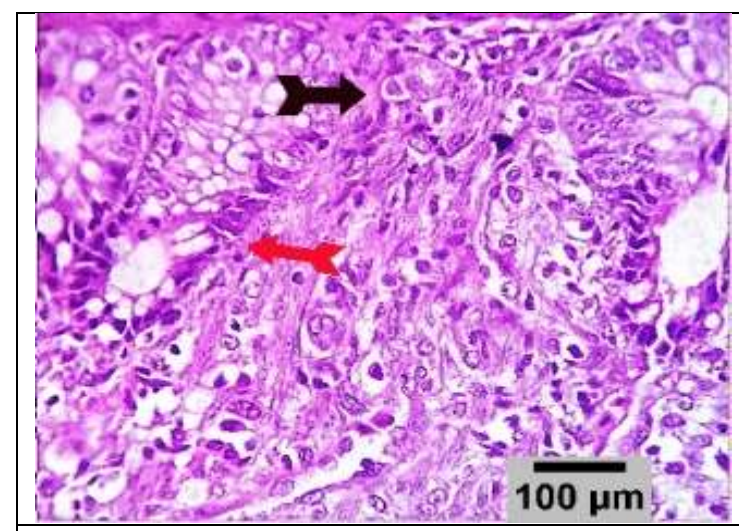

Fig. (8): large intestine from G3showing regenerated epithelium with large hyperchromatic nuclei in glandular epithelium (red arrow)with degenerated bcoccidial developemental stages (blackarrow). Scale bar 100 um. H\&E stain

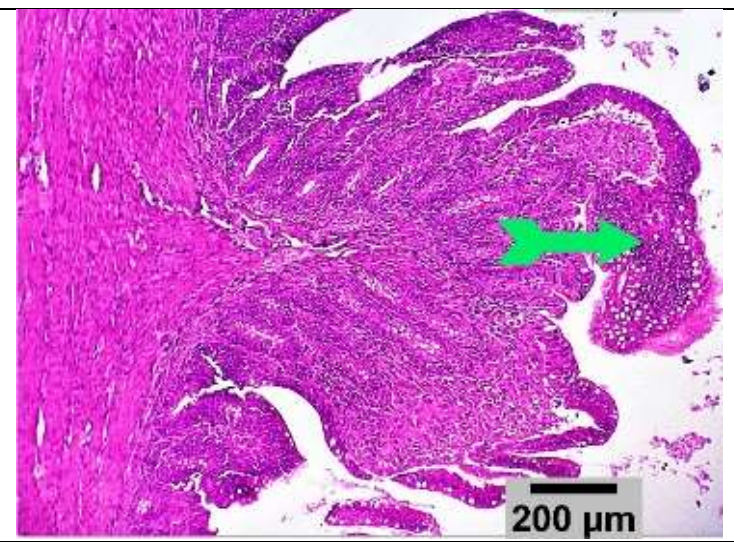

Fig. (10): large intestines from (G 4) showing free intestinal crypts and glands from coccidial developmental stage. Regenerative changes in the crypt and glandular epithelial cells (green arrow). Scale bar 200 um. H\&E stain

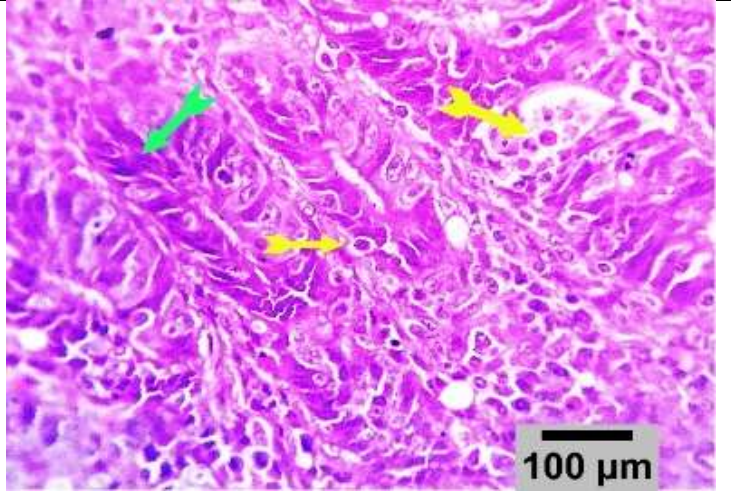

Fig. (9): large intestine from G5 showing developmental stages of coccidia in intestinal crypts and glandular epithelium (yellow arrows). Regenerative changes in the glandular epithelium (green arrow). Scale bar 100 um H\&E stain.

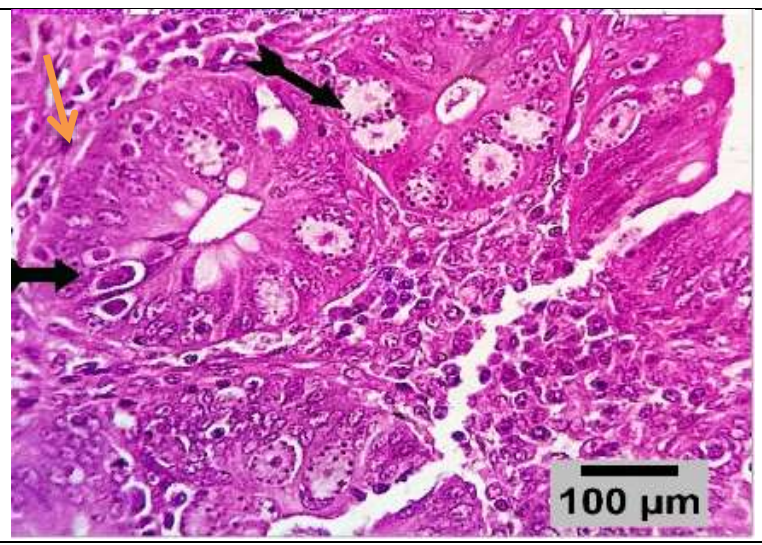

Fig. (11): large intestines from ( $\mathrm{G}$ 6) showing degenerated coccidial developmental stages (black arrows) (A). Infiltration of submucosa by round cells (orange arrow). Scale bar $100 \mathrm{um}$. H\&E stain.

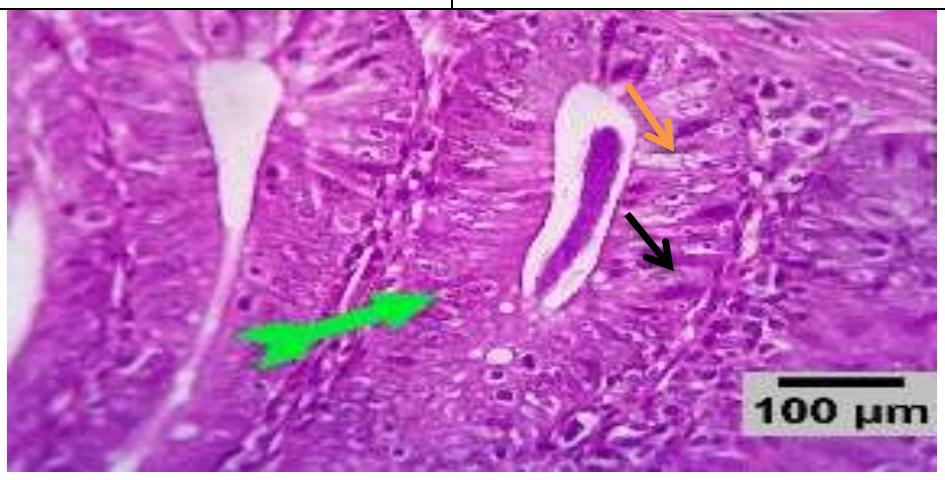

Fig. (12): large intestines from (G 7) showing free intestinal crypts and glands from the parasitic elements (green arrow) Mild submucosal infiltration of round cells (black arrow). Regenerative changes in previously infested cells (orange arrow). Scale bar 100 um. H\&E stain 


\section{DISSCUSION}

For long periods anticoccidal drugs are used successfully to ameliorate the adverse effect coccidia infection in poultry. However, alternatives to combat coccidiosis has become of great importance due to increase in resistance against anticoccidial drugs (Oelschlager et al., 2019). Phytochemicals are emerging as new alternative methods to control coccidiosis (Kaingu et al., 2017). Keeping in view the wide range of Aloe vera and Yucca schidigera activities, the present study was conducted to investigate their ability to alleviates the negative impact of Eimeria infection in broiler chickens.

In the current study, Eimeria challenge significantly reduced growth performance of infected birds including body weight gain, feed intake, and increase FCR as compared with non challenged birds. These results were in close agreement with previous observation showing that growth performance of broiler chickens impaired by coccidia challenge (Kaingu et al., 2017; Oelschlager et al., 2019). Pathological damage of the intestinal wall during Eimeria infection lead to poor nutrient absorption which, in turn decrease weight gain (Kipper et al., 2013). Regarding to effects of Aloe vera gel and Yucca schidigera extract on body weight gain, there was significant increase in body weight gain $(p<0.05)$ in $(\mathrm{G} 3 \& \mathrm{G} 4)$ supplemented with these treatment as prophylactic than $\mathrm{G} 7$ treated with amprolium and (G5\&G6) supplemented with these treatment as therapeutic. On the other hand, there was a significant difference $(\mathrm{P}<0.05)$ in body weight gain between $\mathrm{G} 3 \& \mathrm{G} 4$ while, there was no significant difference $(\mathrm{P}>0.05)$ in body weight gain between G5\&G6. There was no significant difference ( $p>0.05)$ in FCR between all challenged treated groups.

Similar to the finding of the current study, Alfaro et al. (2007) and Bafundo et al. (2020) reported that dietary supplementation of Yucca schidigera extract (YSE) induced significant increase in bodyweight gain and better FCR in broilers challenged with Eimeria as compared to infected non treated groups. On the contrast, Oelschlager et al. (2019) reported that Yucca schidigera extract had no significant influence on growth performance include body weight gain and FCR of broilers challenged with Eimeria. The growth-promoting effects of YSE is attributed to synergistic effect of steroidal saponins and phenolic components that improve nutrient absorption by increasing intestinal permeability (Alagawany et al., 2016). Also, dietary supplementation with saponins result in the emulsification of oil fats, promoting their digestion. (Begum et al., 2015).

Isah et al. (2019) reported that supplementation of drinking water with AV gel significantly increase body weight gain in broilers challenged with coccidia. Also, Ahmad et al. (2020) reported that supplemention of drinking water with AV gel $(5 \mathrm{gm} / \mathrm{L})$ significantly increase body weight gain and decrease FCR in broilers challenged with coccida as compared to control positive groups. On the contrary, Mmereole (2011) reported that dietary inclusion of Aloe vera leaves powder in broilers at $1 \%$ has no significant difference in body weight gains as compared to the control group. Growth hormones (auxins and gibberellins) and polysaccharide (glucomannan) components of Aloe vera able to reduce the inflammation and haemorrhages in the intestines caused by Eimeria infection that led to better digestion and enhanced weight gain (Surjushe et al., 2008). In addition, AV gel contains several beneficial ingredients including vitamins, minerals, enzymes, organic acids, and carbohydrates which could improve productive traits in broilers (Yim et al., 2011).

Regarding to anticoccidial activity, our results showed that yucca schidigera extract and Aloe vera gel significantly reduced the intestinal lesion as compared to positive control group. Among treated groups (G7) and (G4) had less severe lesion score as compared with (G3), (G5) and (G6). These observations agree with those described by Ahmad et al. (2020) who reported that Aloe vera gel reduced intestinal lesions in broilers chickens challenged with 
coccidia as compared to positive control group. Likewise, Bafundo et al. (2020) reported that dietary yucca schidigera extract reduced intestinal lesion in broilers chickens challenged with coccidia.

Concerning the fecal oocyst output, yucca schidigera and aloe vera gel supplementation significantly lower oocyst per gram (OPG) as compared with positive control group. yet, it failed to do as the infected medicated group with amprolium (G7). The highest reduction in (OPG) was $(76.25 \%, 45.31 \% \& 39 \%)$ in $\mathrm{G} 7$, G4\&G3 respectively. While, G5\&G6 had the lowest reduction in OPG $(34.3 \%$ and $32.43 \%)$. The reduction in OPG is an indicative of a lower degree of infection (Kucukyilmaz et al., 2012). The reduction in oocyst count is an evidence of improvement bird immunity to resist coccidian infection. (lee et al., 2013).

These findings corresponded with Alfaro et al. (2007) and Bafundo et al. (2020) who reported that dietary Yucca schidigera reduced oocyst output in broilers challenged with coccidia. The anticoccidial activity of Yucca schidigera might be ascribed to saponins content of Yucca schidigera that inhibit the development of protozoa by interacting with the cholesterol present in the parasite cell membrane, resulting in parasite death (Francis et al., 2002). Also, It was assumed that saponin did not destroy the oocyst's wall but entered the wall through the micropyle cap or gap and directly disturbed the sporocyst (Wina 2018).

In addition, (Yim et al., 2011; Kaingu et al., 2017; Ahmad et al., 2020) reported that dietary supplementation of Aloe vera significantly reduced mean of OPG in coccidia challenged broilers. Aloe vera may interfere with critical stages of Emeria development and reduces damages to the intestinal wall of the chicken by reducing oocysts count, lesion score and haemorrhage (Yim et al., 2011; Kaingu et al., 2017; Ahmad et al., 2020). The polysaccharide derivatives, in Aloe vera gel, has antisporulation effect by interfering in the physiological process necessary for sporulation process like preventing access of oxygen and inhibition of various enzymes responsible for sporulation (Khan 2012). The chemical constituents in Aloe extract as 1, 8 dihydroxyanthraquinone and its derivatives include Aloeemodin, aloetic acid and isobarbaloin act as laxative agents that increase bowel motility. This leads to the quick discharge of coccidial oocysts that are lodged in faecal matter thereby reducing the oocyst count (Nghonjuyi et al., 2015).

Cocidiosis is well known to result in strong intestinal inflammation that is partly mediated by an overexpression of cytokines (Lillehoj et al. 2004). In the current study, Eimeria challenge induced significant increase $(\mathrm{p}<0.05)$ in $I L 6 \& I L-1 \beta$ level in serum of positive control group as compared to other treated groups. Our findings corroborate previous reports increase level of IL-6, IL-1 $\beta$ due to Eimeria infection in chickens, (Hong et al., 2006; Grenier et al., 2016; Moraes et al., 2019). While, supplementation of Yucca schidigera and Aloe vera downregulate levels of IL6\& $I L-1 \beta$. These finding indicate that these supplements exerted an anti-inflammatory effect. Oelschlager et al. (2019) reported that Yucca schidigera extract ameliorated the upregulation of $I L-1 \beta$ level in broiler experimentally challenged with coocidia. Saponin supplementation may possess some measurable immunomodulatory effects during Eimeria infection. YSE is a rich source of polyphenols such as resveratrol (Piacente et al., 2005). Resveratrol could inhibit the NF-jB pathway that result in the decrease transcription of pro inflammatory cytokines like $I L-1 \beta$ and TNF- $\alpha$. (Zhang et al., 2014). Acemannan, a major polysaccharide present in AV gel, appeared to be able to binds to macrophage receptors and stimulates the synthesis of cytokines (interleukin 1 (IL-1), interleukin 6 (IL-6)) and tumor necrosis factor-alpha (TNFa) (Djeraba and Quere 2000.; Darabighane et al., 2012).

The severity of lesions and the number of parasites observed at histological pathological examination are in accordance with the recordings for the macroscopic lesion score and the oocysts counts. At first week after infection, 
all challenged treated groups showed less inflammatory and degenerative changes and reduced coccidial developmental stages as compared to control positive groups. Among treated groups, the most improvement in inflammatory changes and reduction in coccidial developmental stages was observe in (G7) treated with amprolium followed by (G 4) treated with yucca and (G3) treated with aloe vera as prophylactic Similarly, after two weeks post infection (G7) treated with amprolium showed the most improvement where the intestinal crypts and glands were free from any of the parasitic elements and the previously infested cells exhibited regenerative changes. (G4) treated with yucca as prophylactic showed improvement similar to (G7) treated with amprolim where the large intestine appeared free from coccidial stages with marked regenerative changes in crypts and glandular epithelium and absence of inflammatory or hemorrhagic complicating changes of avian coccidiosis. These finding indicates that these supplementation is able to kill or inhibit the growth and development of oocysts, regenerate the damaged cecal tissues and the decrease in inflammatory cells.

Oelschlager et al. (2019) reported that saponin supplementation modified morphological parameters of the jejunum on $14^{\text {th }}$ day following Eimeria challenge by reducing mucosal thickness. Saponin supplementation may promote regeneration and reconstitution of the intestinal mucosal layer back to normal levels as evidenced by saponin treated birds not being significantly different from the unchallenged birds.

Previous studies reported increased Lactobacillus count and reduced Escherichia coli count in the gut of broilers by supplementing diets with AV (Sujatha et al., 2017). Short-chain fatty acids, as the final product of fermentation by Lactobacillus bacteria, improve intestinal morphology and might have stimulated the proliferation of epithelial cells of the bowel (Olnood et al., 2015). In addition, lower crypt depth with Aloe vera supplementation indicated for slow tissue turnover preventing the pathogens from tissue destruction in the gut (Ghazanfari et al., 2015).

\section{CONCLUSION}

In conclusion, the results of the present study demonstrated that Yucca schidigera extract and Aloe vera gel supplementation has great potentials for improving growth performance, intestinal lesions and inflammatory response in broilers under coccidia challenge. Therefore, Yucca schidigera extract and Aloe vera gel may be a potential and valuable candidate to be used as a low cost alternative drugs to control coccidiosis in chickens. Further researches should be done to investigate the therapeutic effect and mechanism of action of Yucca schidigera extract and Aloe vera gel against coccidiosis in broiler chickens.

\section{REFERENCES}

Ahlawat, KS. and Khatkar, BS. (2011): Processing, food applications and safety of aloe vera products: a review. J Food Sci Technol. 48(5): 525-533.

Ahmad, Z.; Hafeez, A.; Ullah, Q.; Naz, S. and Khan, $R U$. (2020): Protective effect of Aloe vera on growth performance, leucocyte count and intestinal injury in broiler chicken infected with coccidiosis. J Appl Anim Res. 48(1): 252-256.

Akhtar, M.; Tariq, AF.; Awais, MM.; Iqbal, Z.; Muhammad, F.; Shahid, M. and HiszczynskaSawicka, E. (2012): Studies on wheat bran Arabinoxylan for its immunostimulatory and protective effects against avian coccidiosis. Carbohydr Polym. 90(1): 333-339.

Akram, MZ.; Salman, M.; Jalal, H.; Asghar, U.; Zeshan, ALI.; Javed, Mh. and Minahil, K. (2019): Evaluation of dietary supplementation of Aloe vera as an alternative to antibiotic growth promoters in broiler production. Turkish J Vet Res. 3(1): 21-26.

Alagawany, M.; Abd El-Hack, ME. and El-Kholy, $M S$. (2016): Productive performance, egg quality, blood constituents, immune functions, and antioxidant parameters in laying hens fed diets with different levels of Yucca schidigera extract. Environ Sci Pollut Res. 23(7): 6774-6782. 
Alagawany, MM.; Farag, MR.; Kuldeep, D.; ElHack, MEA.; Ruchi, T. and Alam, GM. (2015): Mechanisms and beneficial applications of resveratrol as feed additive in animal and poultry nutrition: a review. Int $\mathbf{J}$ Pharmacol. 11(3): 213-221.

Alfaro, DM.; Silva, AVF.; Borges, SA.; Maiorka FA.; Vargas, S. and Santin, E. (2007): Use of Yucca schidigera extract in broiler diets and its effects on performance results obtained with different coccidiosis control methods. $\mathbf{J}$ Appl Poult Res. 16(2): 248-254.

Alnassan, AA.; Shehata, AA.; Kotsch, M.; Schrödl, W.; Krüger, M.; Daugschies, A. and Bangoura, B. (2013): Efficacy of early treatment with toltrazuril in prevention of coccidiosis and necrotic enteritis in chickens. Avian Pathol. 42(5): 482-490.

Bafundo, KW.; Johnson, AB. and Mathis, GF. (2020): The Effects of a Combination of Quillaja saponaria and Yucca schidigera on Eimeria spp. in Broiler Chickens. Avian Dis. 64(3): 300-304.

Barnes, HJ.; Vaillancourt, JP. and Gross, W. (2003): Colibacillosis, p 631-656. InSaif Y (ed), Diseases of poultry.

Begum, M.; Hossain, MM. and Kim, IH. (2015): Effects of caprylic acid and Yucca schidigera extract on growth performance, relative organ weight, breast meat quality, haematological characteristics and caecal microbial shedding in mixed sex Ross 308 broiler chickens. Vet Med (Praha). 60(11).

Cervantes, HM. (2015): Antibiotic-free poultry production: is it sustainable? J Appl Poult Res. 24(1): 91-97.

Cheeke, PR.; Piacente, S. and Oleszek, W. (2006): Anti-inflammatory and anti-arthritic effects of Yucca schidigera: a review. J Inflamm. 3(1): $1-7$.

Choi, S. and Chung, M-H. (2003): A review on the relationship between Aloe vera components and their biologic effects. In: Seminars in integrative medicine. Vol. 1. Elsevier. p. 5362.

Christaki, EV. and Florou-Paneri, PC. (2010): Aloe vera: a plant for many uses. J Food Agric Env. 8(2): 245-249.

Clark, EL.; Macdonald, SE.; Thenmozhi, V.; Kundu, K.; Garg, R.; Kumar, S.; Ayoade, S.; Fornace, KM.; Jatau, ID. and Moftah, A. (2016): Cryptic Eimeria genotypes are common across the southern but not northern hemisphere. Int J Parasitol. 46(9): 537-544.
Darabighane, B.; Zarei, A. and Shahneh, AZ. (2012): The effects of different levels of Aloe vera gel on ileum microflora population and immune response in broilers: a comparison to antibiotic effects. J Appl Anim Res. 40(1): 31-36.

Djeraba, A. and Quere, P. (2000): In vivo macrophage activation in chickens with Acemannan, a complex carbohydrate extracted from Aloe vera. Int $\mathrm{J}$ Immunopharmacol. 22(5): 365-372.

Djezzar, R.; Benamirouche, K.; Baazize-Ammi, D.; Mohamed-Said, R. and Guetarni, D. (2014): Effect of a dietary supplementation combining a probiotic and a natural anticoccidial in broiler chickens. African J Agric Res. 9(52): 3782-3788.

Du, X.; Chen, X.; Zhao, B.; Lv, Y.; Zhang, H.; Liu, H.; Chen, Z.; Chen, Y. and Zeng, X. (2011): Astragalus polysaccharides enhance the humoral and cellular immune responses of hepatitis B surface antigen vaccination through inhibiting the expression of transforming growth factor $\beta$ and the frequency of regulatory $\mathrm{T}$ cells. FEMS Immunol Med Microbiol. 63(2): 228-235.

Francis, G.; Kerem, Z.; Makkar, HPS. and Becker, $K$. (2002): The biological action of saponins in animal systems: a review. Br J Nutr. 88(6): 587-605.

Ghazanfari, S.; Mohammadi, Z. and Adib Moradi, M. (2015): Effects of coriander essential oil on the performance, blood characteristics, intestinal microbiota and histological of broilers. Brazilian J Poult Sci. 17(4): 419426.

Gibbons, P.; Love, D.; Craig, T. and Budke, C. (2016): Efficacy of treatment of elevated coccidial oocyst counts in goats using amprolium versus ponazuril. Vet Parasitol. 218: $1-4$.

Grenier, B.; Dohnal, I.; Shanmugasundaram, R.; Eicher, SD.; Selvaraj, RK.; Schatzmayr, G. and Applegate, TJ. (2016): Susceptibility of broiler chickens to coccidiosis when fed subclinical doses of deoxynivalenol and fumonisins-Special emphasis on the immunological response and the mycotoxin interaction. Toxins (Basel). 8(8): 231.

Hong, YH.; Lillehoj, HS.; Lee, SH.; Dalloul, RA. and Lillehoj, EP. (2006): Analysis of chicken cytokine and chemokine gene expression following Eimeria acervulina and Eimeria tenella infections. Vet Immunol Immunopathol. 114(3-4): 209-223. 
Huang, G.; Tang, X.; Bi, F.; Hao, Z.; Han, Z.; Suo, J.; Zhang, S.; Wang, S.; Duan, C. and $Y u, Z$. (2018): Eimeria tenella infection perturbs the chicken gut microbiota from the onset of oocyst shedding. Vet Parasitol. 258: 30-37.

Isah, MM.; Gide, S.; Haruna, A. and Anas G. (2019): Antiprotozoal Effects of Aloe vera Leaves Extract against Experimentally Induced Coccidiosis in Broiler Chickens. South Asian J Parasitol.: 1-7.

Kaingu, F.; Liu, D.; Wang, L.; Tao, J.; Waihenya, $R$. and Kutima, H. (2017): Anticoccidial effects of Aloe secundiflora leaf extract against Eimeria tenella in broiler chicken. Trop Anim Health Prod. 49(4): 823-828.

Kar, SK. and Bera, TK. (2018): Phytochemical constituents of Aloe vera and their multifunctional properties: A comprehensive review. Int J Pharm Sci Res. 9(4): 14161423.

Khan, MN. (2012): Anticoccidial activity of herbal complex in broiler chickens challenged with Eimeria tenella. Parasitology. 139(2): 237243.

Kipper, M.; Andretta, I.; Lehnen, CR.; Lovatto, PA. and Monteiro, SG. (2013): Meta-analysis of the performance variation in broilers experimentally challenged by Eimeria spp. Vet Parasitol. 196(1-2): 77-84.

Lee, KW.; Lillehoj, HS.; Jang, SI.; Pagès, M.; Bautista, DA.; Pope, CR.; Ritter, GD.; Lillehoj, EP.; Neumann, AP. and Siragusa, $G R$. (2012): Effects of in ovo vaccination and anticoccidials on the distribution of Eimeria spp. in poultry litter and serum antibody titers against coccidia in broiler chickens raised on the used litters. Res Vet Sci. 93(1): 177-182.

Lillehoj, HS.; Min, W. and Dalloul, RA. (2004): Recent progress on the cytokine regulation of intestinal immune responses to Eimeria. Poult Sci. 83(4): 611-623.

Lin, J.; Zhang, FY.; Xu, Y.; Ting, ZX. and Po, YD. (2005): Effects of gel, polysaccharide and acemannan from Aloe vera on broiler gut flora, microvilli density, immune function and growth performance. Chinese J Vet Sci. 25(6): 668-671.

Mmereole, FUC. (2011): Evaluation of the dietary inclusion of aloe vera as an alternative to antibiotic growth promoter in broiler production. Pakistan J Nutr. 10(1): 1-5.

Moraes, PO.; Andretta, I.; Cardinal, KM.; Ceron, M.; Vilella, L.; Borille, R.; Frazzon, AP.; Frazzon, J.; Santin, E. and Ribeiro, AML. (2019): Effect of functional oils on the immune response of broilers challenged with Eimeria spp. animal. 13(10): 2190-2198.

Munir, HA.; Akbar, H.; Lateef, M.; Rashid, I.; Akhtar, R.; Nazir, J. and Farooqi, SH. (2018): Anticoccidial activity of different forms of Aloe vera. Indian J Anim Res. 52(3).

Nghonjuyi, NW.; Kimbi, HK.; Keambou, CT.; Manka'a, CN.; Toukala, JP.; Juliano, RS. and Lisita, F. (2015): Assessment of anticoccidial efficacy of ethanolic extract of Aloe vera leaf in Kabir chicken in Cameroon. $\mathrm{J}$ Adv Parasitol. 2(2):23-29.

Noack, S.; Chapman, HD. and Selzer, PM. (2019): Anticoccidial drugs of the livestock industry. Parasitol Res. 118(7): 2009-2026.

Oelschlager, ML.; Rasheed, MSA.; Smith, BN.; Rincker, MJ. and Dilger, RN. (2019): Effects of Yucca schidigera-derived saponin supplementation during a mixed Eimeria challenge in broilers. Poult Sci. 98(8): 32123222.

Olnood, CG.; Beski, SSM.; Choct, M. and Iji, PA. (2015): Novel probiotics: Their effects on growth performance, gut development, microbial community and activity of broiler chickens. Anim Nutr. 1(3): 184-191.

Piacente, S.; Pizza, C. and Oleszek, W. (2005): Saponins and phenolics of Yucca schidigera Roezl: Chemistry and bioactivity. Phytochem Rev. 4(2): 177-190.

Radha, MH. and Laxmipriya, NP. (2015): Evaluation of biological properties and clinical effectiveness of Aloe vera: A systematic review. J Tradit Complement Med. 5(1): 21-26.

Sahoo, SP.; Kaur, D.; Sethi, APS.; Sharma, A. and Chandra, M. (2015): Evaluation of Yucca schidigera extract as feed additive on performance of broiler chicks in winter season. Vet World. 8(4): 556.

Sainsbury, D. (1984): System of management in "Poultry health and management".

Sujatha, T.; Abhinaya, S.; Sunder, J.; Thangapandian, M. and Kundu, A. (2017): Efficacy of early chick nutrition with Aloe vera and Azadirachta indica on gut health and histomorphometry in chicks. Vet world. 10(6):569.

Sun, D.; Jin, X.; Shi, B.; Su, J.; Tong, M. and Yan, S. (2017): Dietary Yucca schidigera extract improved growth performance and liver antioxidative function in broilers. Ital J Anim Sci. 16(4): 677-684. 
Surjushe, A.; Vasani, R. and Saple, DG. (2008): Aloe vera: a short review. Indian J Dermatol. 53(4): 163.

Suvarna, KS.; Layton, C. and Bancroft, JD. (2018): Bancroft's theory and practice of histological techniques E-Book. Elsevier Health Sciences.

Tanweer, AJ.; Saddique, U.; Bailey, CA. and Khan, $R U$. (2014): Antiparasitic effect of wild rue (Peganum harmala L.) against experimentally induced coccidiosis in broiler chicks. Parasitol Res. 113(8): 2951-2960.

Thenmozhi, V.; Veerakumari, L. and Raman, M. (2014): Preliminary genetic diversity study on different isolates of Eimeria tenella from South India. Int J Adv Vet Sci Technol. 3(1): 114-118.

Wina, E. (2018): The role of saponin as feed additive for sustainable poultry production.

Yim, D.; Kang, SS.; Kim, DW.; Kim, SH.; Lillehoj, HS. and Min, W. (2011): Protective effects of Aloe vera-based diets in Eimeria maximainfected broiler chickens. Exp Parasitol. 127(1): 322-325.

Youn, HJ. and Noh, JW. (2001): Screening of the anticoccidial effects of herb extracts against Eimeria tenella. Vet Parasitol. 96(4): 257263.

Zhang, C.; Tian, Y.; Yan, F.; Kang, X.; Han, R.; Sun, G. and Zhang, H. (2014): Modulation of growth and immunity by dietary supplementation with resveratrol in young chickens receiving conventional vaccinations. Am J Vet Res. 75(8): 752-759.

\section{الفعاليه المحتمله لجل الصبار ومستخلص اليوكا على مقاييس التمو والافات المعويه والاستجابه

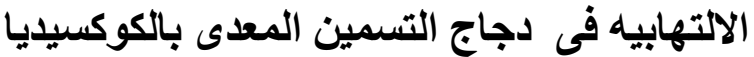

\section{غاده علام عبل/لد/بيم ، ريحاب رشاد عبل/لمجيل ، نسعه رشبل}

E-mail: anasesra@gmail.com

Assiut University web-site: www.aun.edu.eg

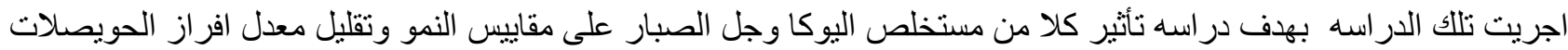

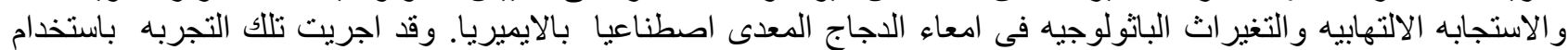

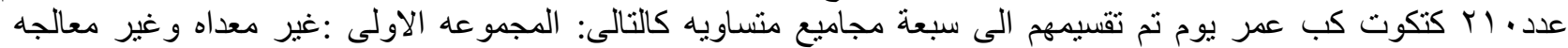

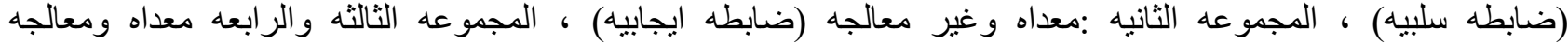

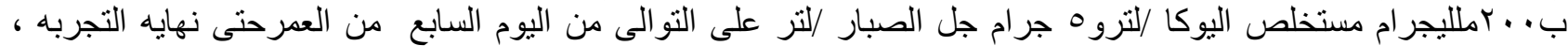

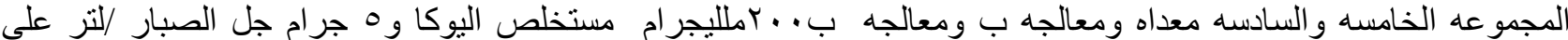

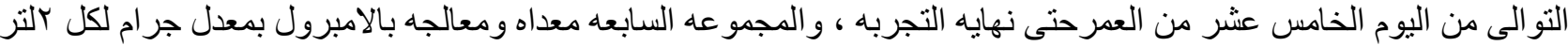

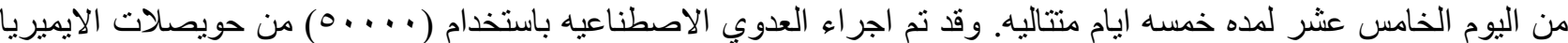

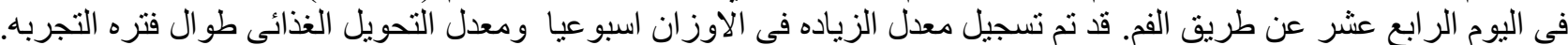

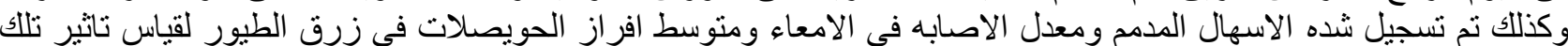

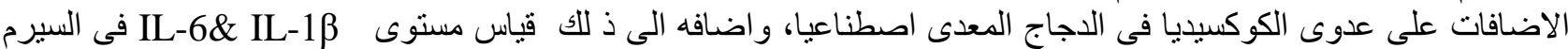

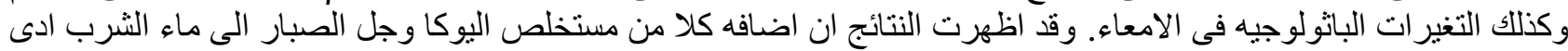

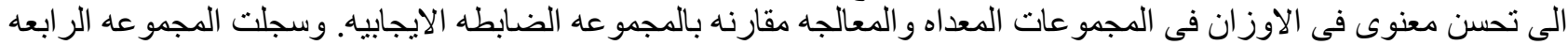

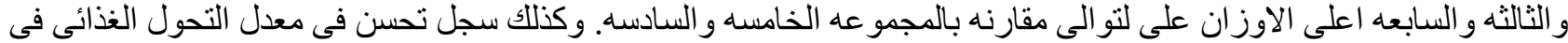

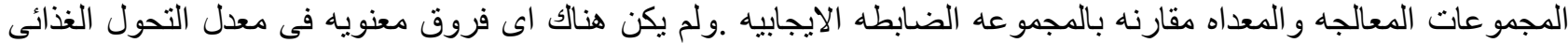

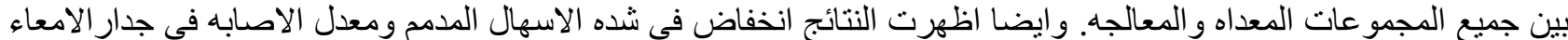

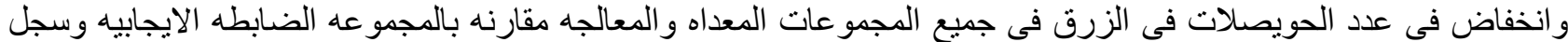

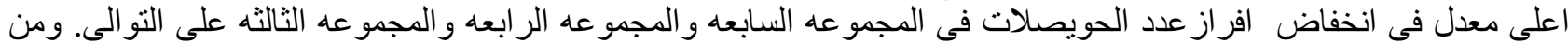

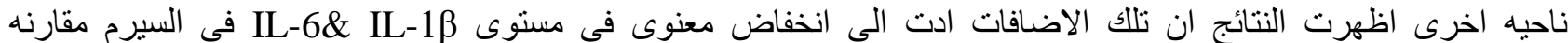

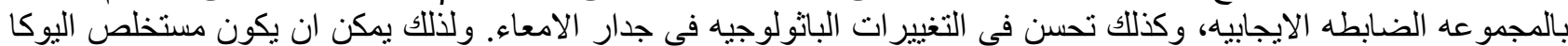
وجل الصبارمن المستحضر ات الو اعده لاستخدامه كبديل طبيعى منخفض التكلفه لمكافحة عدوي الإهعاه ولكوكسيديا في الدجاج. 